\title{
WOUND HEALING EFFECT OF KING ALFERD'S MUSHROOM (DALDINIA CONCENTRICA) USED BY TRIBES OF SIRUMALAI HILLS, TAMILNADU, INDIA
}

\author{
RAJESHWARAN THANGARAJ, SUMATHY RAJ, KUMUTHAKALAVALLI RENGANATHAN
}

Department of Biology, The Gandhigram Rural Institute-Deemed University, Gandhigram 624302, Dindigul, Tamilnadu, India

Email: sumathysaravanan.31@gmail.com

Received: 03 May 2015 Revised and Accepted: 10 Dec 2015

\section{ABSTRACT}

Objective: The present investigation is an attempt to an ethnomycological mushroom survey carried out among the paliyar tribals of five settlements in Sirumalai hills. Daldinia concentrica, mushroom reported by the tribals for the wound healing activity was evaluated in vivo in rat model.

Methods: The indigenous information of the tribal people was collected through personal interviews during field trips and also the ethno reported mushroom Daldinia concetrica was analysed for its phytochemical constituents by Harborne method and its potential wound healing activity in Albino Wistar rats by excision wound model.

Results: The exploration revealed that $92 \%$ of the respondents consume mushroom as food and four mushrooms are used in ethnomedicine in the study area namely, Daldinia concentrica, Calvatia gigantean, Termitomyces microcarpus and Podaxis pistillaris. Daldinia concentrica for wound healing, is the first ethnomycological report, thus the further study on Daldinia revealed that the mushroom sample consists of alkaloid $0.97 \pm 0.07$ $\mathrm{mg} / \mathrm{kg}$, flavanoid $2.97 \pm 0.12 \mathrm{mg} / \mathrm{kg}$, phenol $0.32 \pm 0.01 \mathrm{mg} / \mathrm{kg}$, tannin $0.17 \pm 0.02 \mathrm{mg} / \mathrm{kg}$, terpenoid $0.07 \pm 0.01 \mathrm{mg} / \mathrm{kg}$ and saponin $0.09 \pm 0.02 \mathrm{mg} / \mathrm{kg}$; and it's in vivo wound healing activity was found to be outstanding around $75-87 \%$ compared to that of the commercial ointment neosporin.

Conclusion: We believe that wound healing activity of Daldinia mushroom was due to the synergestic effect of phytochemicals present in them. Our results throw in the insight of the traditional use of mushrooms in various treatments.

Keywords: Ethnomedicine, Paliyars, Phytochemicals, Wistar rats, Wound healing

(C) 2017 The Authors. Published by Innovare Academic Sciences Pvt Ltd. This is an open access article under the CC BY license (http://creativecommons.org/licenses/by/4.0/) DOI: http://dx.doi.org/10.22159/ijpps.2017v9i7.20628

\section{INTRODUCTION}

Worldwide 200 million tribal communities live in and depend on forests for their livelihood, food, medicine and shelter. Tribal people are the repository of accumulated experience and knowledge of indigenous flora and fauna [1]. India is in habituated by over 50 million tribal people belonging to about 550 tribal communities. State of Tamilnadu houses more than 36 tribal communities who commonly referred as scheduled tribes, adivasis, indigenous people and aborigines [2].

Ethnomycology is the study of the use of fungi by human and also it gives details on relationship between traditional societies and fungi. The ethnomycological knowledge of mushrooms dated back to millennia, and its empirical documentation is a more recent phenomenon. Ethnomycology popularizes the diversity of useful mushroom species over the poisonous ones and provides insight into their culinary and medicinal use. These indigenous documentation laid foundation for many mushroom research, resulting in new exploration of valuable mushrooms and mushroom products [3]. Ethnomycological works are prolific and represent diverse areas of mushroom knowledge that includes entheogenics, cultivation, nutraceutics, mushroom taxonomy, mycophagy and mycopharmaceuticals [4]. Intrinsic and systematic studies are required for the exploration of valuable and valueless mushrooms, and advanced scientific insights are required to assess their usage and potentiality towards human behavior and many diseased conditions.

Wild mushroom tend to grow on areas with high humidity and rainfall. They are important contributions to rural and tribal livelihoods. Sirumalai hills lies in the Eastern Ghats, Dindigul district, Tamilnadu. The hill lies between $10^{\circ} 07^{\prime}-10^{\circ} 18^{\prime} \mathrm{N}$ latitude and 77 ${ }^{\circ} 55^{\prime}-78^{\circ} 12^{\prime} \mathrm{E}$ longitude. It covers $52 \mathrm{Km}^{2}$ hill range with an average temperature of $26 \pm 2{ }^{\circ} \mathrm{C}$ in summer and $10 \pm 2{ }^{\circ} \mathrm{C}$ in winter [5]. Paliyars happen to be one of the dominant tribals of Sirumalai hills; they usually live at an altitude of $900-1350 \mathrm{~m}$ in isolated settlements on the hill slopes [6].
A scrutiny of literature revealed that no attempts were made on documentation of mushrooms for medicinal use from paliyar tribes. The objective of this study was to assess the richness of ethno mycological mushroom species used by the paliyar tribes in Sirumalai hills, Dindigul district forest areas to treat various illness. In addition, the collected information on the mushroom species Daldinia concentrica, was analysed scientifically by analyzing the phytochemical constituents and their in vivo wound healing activity in Albino Wistar Rats.

Wounds are inescapable events of life, which arise due to physical or chemical injury or microbial infections [7]. It is an important biological process involving tissue repair and regeneration. Wound healing can be classified into any of three types (ie.) healing by first intention, healing by second intention or healing by third intention, depending on the nature of the edges of the healed wounds [8]. Research on drugs that increase wound healing is a developing area in modern biomedical sciences. Plant based wound healing activity reported that the activity is due to the presence of wide spectrum of phytochemicals [9]. The, present study is a first attempt to confirm the folkloric claim of the wound healing activity of the King Alferd's Mushroom, Daldinia concentrica.

\section{MATERIALS AND METHODS}

\section{Study area}

The study area Sirumalai hill lies between $10^{\circ} 07^{\prime}-10^{\circ} 18^{\prime} \mathrm{N}$ latitude and $77^{\circ} 55^{\prime}-78^{\circ} 12^{\prime} \mathrm{E}$ longitude. Ethno mycological information was collected from the aged elders, village vaidyars and experienced local tribals through personal interview. The information was confirmed by investigating through two or more informants from different settlements of Paliyars in Sirumalai hills, Tamilnadu.

For the further study, the mushroom species Daldinia concentrica, were collected by uprooting their substratum, with the aid of a sharp knife. Prior to collection, photographs were taken at their natural environment. The mushroom were covered in a tissue paper and 
placed carefully in the zip-lock bags. The specimen was identified in the laboratory using the reported procedures [10] and with the help of mycologists. The voucher specimen was deposited in the mushroom lab, Department of Biology, The Gandhigram Rural Institute-Deemed University, Dindigul, Tamilnadu.

\section{Phytochemical analysis}

The mushroom samples after removal of external materials such as mud, soil and wood debris by washing with demineralised water, were air dried between filter papers for removal of excess water. A fine dried powder of mushroom sample $10 \mathrm{~g}$ was extracted by stirring with $100 \mathrm{ml}$ of methanol at $25^{\circ} \mathrm{C}$ at $150 \mathrm{rpm}$ for $24 \mathrm{~h}$ and filtered through Whatman No-4 filter paper. The residue was then extracted with two additional $100 \mathrm{ml}$ portions of methanol, as described above. The combined methanolic extracts were evaporated at $40{ }^{\circ} \mathrm{C}$ to dryness. The methanol extract was used for the estimation of phytochemicals by Harborne [11] method.

\section{In vivo wound healing activity [12]}

Wistar rats of both sex weighing 150-200g were used for this study. The animals were obtained from animal house, IRT Perundurai medical college, Erode, Tamilnadu, India. On arrival, the animals were placed randomly and allocated to treatment groups in polypropylene cages with paddy husk as bedding. Animals were housed at a temperature of $24 \pm 2{ }^{\circ} \mathrm{C}$ and relative humidity of $30-70 \%$. A12:12 light: day cycle was followed. All the animals were allowed to free access to water and fed with standard commercial pelleted chew (M/s. Hindustan Lever Ltd., Mumbai). All the experimental procedures and protocols used in this study were in accordance with the guidelines of the Institutional Animal Ethical Committee (IAEC), with the Institutional Animal Ethics Committee (688/2/C-CPCSEA) of Nanda College of Pharmacy, Perundurai, Erode, Tamilnadu, Dindigul.

\section{Excision wound model}

The experimental animals were grouped in to four containing six animals each and treated as follows:

Group I: Received control-Ointment Base (Untreated)

Group II: Received Commercial Neosporin ointment (Positive Control)

Group III: Received test ointment, (5\% w/w) of the mushroom extract.

Group IV: Received test ointment, $(10 \% \mathrm{w} / \mathrm{w})$ of the mushroom extract.

A circular wound of about $500 \mathrm{~m}^{2}$ was made by remove depilating the skin on dorsal thoracic region of rats under light ether anesthesia in aseptic condition and observed throughout the study. Animals were housed individually. All the test drugs were applied on the wounded area twice daily. Wound contraction was measured on $1 \mathrm{st}, 3 \mathrm{rd}, 7 \mathrm{th}, 14^{\text {th }}$ and $21^{\text {st }}$ post wounding days. $\%$ of wound contraction was calculated from the day of measurement of wound area.

\section{Statistical analysis}

All experiments were conducted in triplicates and the parameters were given as means \pm standard error. Both mean and standard deviation were performed, using the statistical package within Microsoft ${ }^{\circledR}$ Excel Version 2007. Ink and the graphs were plotted using software Origin 6.0.
All the results of wound healing experiments were expressed as mean \pm standard error mean (SEM). Data were analyzed using oneway ANOVA followed by Dunnett's $t$-test. The analysis was carried out using Graph pad software of version 4. $\mathrm{p}<0.05$ was considered as statistically significant.

\section{RESULTS}

Mushrooms are abundantly available throughout the world, and are mainly focused than ever before because they have the capability of producing many benefits indeed to mankind especially in the field of medicine. The present exploration exposes that mushrooms are being used by the paliyar tribals to treat various diseases. Data's from the informants revealed that four different mushroom species are mainly used by them for curing diseases. Daldinia concentrica is being used for curing skin irritations and wound healing; Calvatia gigantean used for curing stomach upset and to cure stomach pains in woman during menstruation; Termitomyces microcarpus to treat male infertility and male visceral organ infections and Podaxis pistillaris to cure skin diseases and skin burns.

Out of these four the other three mushrooms have been reported already for their medicinal uses except the mushroom Daldinia concentrica, under Xylariaceae family, commonly called as King Alfred's Cake is being used for wound healing by the tribals. This mushroom is being used in the form of dried powder and applied topically for any wound. The wound healing of Daldinia concentrica is the first ethno mycological report. Further in depth phytochemical analysis on Daldinia revealed the presence of wide spectrum of phytochemicals (table 1).

Table 1: Phytochemical composition of Daldinia concentrica

\begin{tabular}{ll}
\hline Parameters & Composition $(\mathbf{m g} / \mathbf{k g})$ \\
\hline Alkaloid & $0.97 \pm 0.07$ \\
Flavanoid & $2.97 \pm 0.12$ \\
Tannin & $0.17 \pm 0.02$ \\
Terpenoid & $0.07 \pm 0.01$ \\
Saponin & $0.09 \pm 0.02$ \\
Phenols & $0.32 \pm 0.01$ \\
\hline
\end{tabular}

The wound healing activity of $5 \%$ and $10 \%$ methanolic extract of mushroom were studied on excision wound model in rats (table 2 and 3). Neosporin was used as reference control. Wound contraction was measured on $1^{\text {st }}, 3^{\text {rd }}, 7^{\text {th }}, 14^{\text {th }}$ and $21^{\text {st }}$ post wounding days. \% of wound contraction was calculated from the day of measurement of wound area (fig. 1). Both the extracts showed significant $(\mathrm{P}<0.05)$ wound contraction from $7^{\text {th }}$ day onwards and percentage wound contraction was $35.52 \%$ and $39.80 \%$ respectively.

The Neosporin ointment showed significant $(\mathrm{P}<0.05)$ wound contraction from $3^{\text {rd }}$ day onwards and on $7^{\text {th }}, 14^{\text {th }}$ and $21^{\text {st }}$ day of $\%$ wound contraction was $42.27 \%, 75.26 \%$ and $92.24 \%$ respectively. The $5 \%$ mushroom extract showed $47.29 \%$ and $75.64 \%$ wound contraction on $14^{\text {th }}$ and $21^{\text {st }}$ days of the study respectively, the $10 \%$ mushroom extract showed $73.62 \%$ and $87.78 \%$ wound contraction on $14^{\text {th }}$ and $21^{\text {st }}$ days of the study respectively. Among the $5 \%$ and $10 \%$ mushroom extract, $10 \%$ mushroom extract showed good wound healing activity.

Table 2: Effect of Daldinia concentrica on wound contraction in albino rats

\begin{tabular}{|c|c|c|c|c|c|}
\hline \multirow[t]{2}{*}{ Drug treatment } & \multicolumn{5}{|c|}{ Wound contraction (day) } \\
\hline & 1 & 3 & 7 & 14 & 21 \\
\hline Control(Ointment Base) & $11.55 \pm 0.33$ & $42.49 \pm 1.98$ & $71.14 \pm 3.66$ & $106.04 \pm 9.37$ & $196.12 \pm 15.21$ \\
\hline Neosporin ointment & $25.23 \pm 1.09$ & $76.13 \pm 6.37^{*}$ & $211.35 \pm 9.58^{* * *}$ & $376.32 \pm 16.97^{* * *}$ & $461.22 \pm 22.77^{* * *}$ \\
\hline 5\% Extract & $20.15 \pm 0.86$ & $48.26 \pm 3.57$ & $177.59 \pm 6.35^{*}$ & $263.47 \pm 11.25^{* *}$ & $378.22 \pm 21.33^{* * *}$ \\
\hline $10 \%$ Extract & $23.59 \pm 1.44$ & $57.69 \pm 3.65$ & $199.00 \pm 12.56^{*}$ & $368.12 \pm 20.14^{* * *}$ & $438.90 \pm 22.47^{* * *}$ \\
\hline
\end{tabular}

Values are in mean \pm SEM $(\mathrm{n}=6)-{ }^{*} \mathrm{P}<0.05$ and ${ }^{* *} \mathrm{P}<0.01$ Vs Control Group 

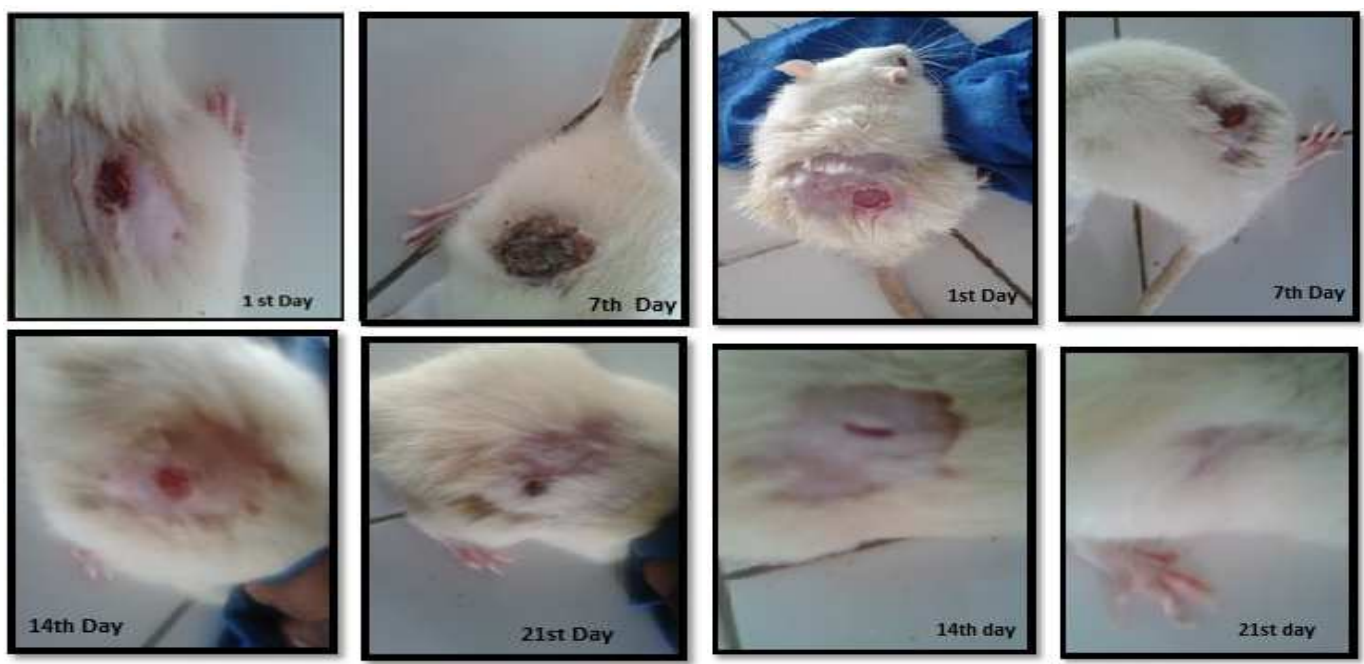

Goup - 1 - Control - Oinment Base

Group-2-Control-Neosporin
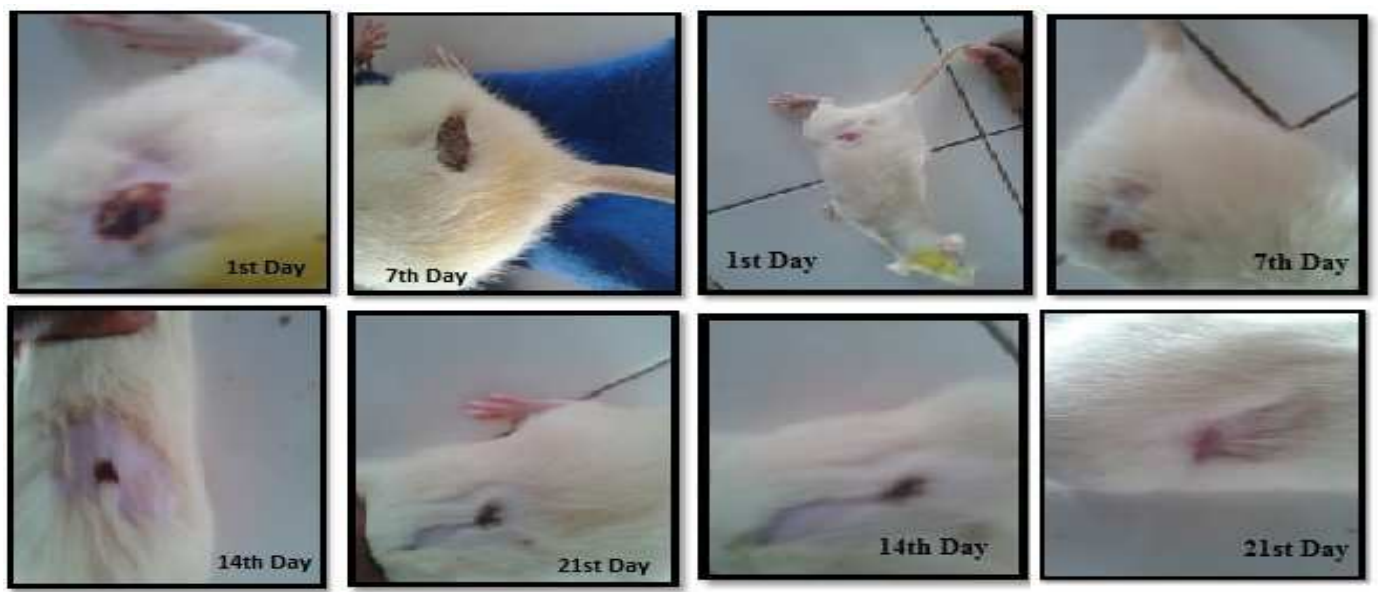

Group - 3 - Test - 5\% Mushroom Extract

Group - 4 - Test - 10\% Mushroom Extract

Fig. 1: Wound healing activity of Daldinia concentrica on albino wistar rats

Table 3: Percentage wound healing activity of Daldinia concentrica

\begin{tabular}{lllll}
\hline Drug treatment & \% wound healing (Day) & & \\
\cline { 2 - 5 } & $\mathbf{1}$ & $\mathbf{3}$ & $\mathbf{7}$ & $\mathbf{2 1}$ \\
\hline Control(Ointment Base) & 2.31 & 8.50 & 14.23 & 21.21 \\
Neosporin ointment & 5.05 & 15.23 & 42.27 & 75.26 \\
5\% extract & 4.03 & 9.65 & 35.52 & 47.22 \\
$10 \%$ extract & 4.72 & 11.54 & 39.80 & 73.62 \\
\hline
\end{tabular}

\section{DISCUSSION}

The use of mushrooms as medicine is widespread throughout the world. The mushroom and mushroom products have augmented human culture since time immemorial. The documentation of indigenous knowledge on the utilization of natural resources by different ethnic groups or communities is one of the main objectives of ethnobotanical research [13]. Thus there is enormous scope for ethnomedico botanical studies in our country. Tamil Nadu is spotted with tribal pockets rich in germplasm of medicinal plants [14]. Paliyars the dominant tribals of Sirumalai hills, Eastern Ghats, Dindigul district, Tamil Nadu are one among them.

Wound healing is the process of repair that follows injury to the skin and other soft tissues. It is fundamentally a connective tissue response. Initial stages of wound healing involve an acute inflammatory phase followed by synthesis of collagen and other extracellular matrix which are later remodeled to form scar [15]. Fungal drugs have come to be increasingly used worldwide because of their effectiveness and safety. Mushrooms are used medicinally for many ailments and disorders [16]. One among the mushrooms, Daldinia concentrica, King Alfred's cake is reported to have antibacterial, anti-fungal, antioxidant properties [17]. And also this higher fungus with other medicinal ingredients has been used by traditional doctors in Yorubaland, South Western Nigeria in the treatment of pneumonia and other bacterial infections [18]. Both cellular components and secondary metabolites of a large number of mushrooms and other green plants have been shown to affect the immune system of the host and therefore could be used to treat a variety of diseases [19]. The report was in agreement with our findings that Daldinia concentrica consists of wide range of major and minor elements. And it was also evident from the earlier reports that the therapeutic property of the mushroom may be due to the presence of wide spectrum of phytochemicals present in it [20]. Thus, all these reported characteristics of Daldinia extracts viz, antiinflammation, antioxidant and antimicrobial are the main properties of remedies which would have accelerated wound healing in rats. 
Keeping in view the tremendous pharmacological activities and a wealth of available literature and from tribal report, Daldina concentrica was tested for its wound healing activity. In excision wound, both the extracts ( $5 \%$ and $10 \%$ ) showed faster healing compared with control groups and wound contraction rate is faster with $10 \%$ extract as compared with $5 \%$ extract. Present results were in agreement with the earlier works of wound healing activity in rats with extracts of Aloe vera [21]; Quercus infectoria [22] and Ocimum sanctum [23].

\section{CONCLUSION}

In the present study extract prepared with Daldinia concentrica exhibited an excellent wound healing effect comparable to those of Neosporin, a standard antibiotic used in wound healing. This finding thus, justifies its use in folkloric medicine for wound healing. Since Daldinia concentrica is ubiquitous and abundantly grown, it could be a fairly economical therapeutic agent for wound management as a prohealer, as well as to control abnormal healing. This is the first report on the usage of the King Alfred's Mushroom, Daldinia concentrica on wound healing. Further research should be focused to isolate the active compounds from Daldinia concentrica mushrooms having medicinal properties and to commercialize their production and marketing.

\section{CONFLICT OF INTERESTS}

Declared none

\section{REFERENCES}

1. Jain SK. Dictionary of Indian folk medicine and Ethnobotany. Deep publication New Delhi; 1991.

2. Sanjay Paswan, Paramanshi Aideva. Encyclopedia of Dalit's in India: Movements, Kalpaz Publications, India; 2002.

3. De Kesel A, Degreef J. Ethnomycological research and literature surveys from Africa. Mycoafrica 2007;2:4-5.

4. Wasser SP. Current findings, future trends and unsolved problems in studies of medicinal mushrooms. Appl Microbiol Biotechnol 2010;89:1323-32.

5. Champion HG, Seth SK. A revised survey of forest types of India, Government of India Press, Delhi; 1968.

6. Karuppusamy S, Rajasekaran KM, Karmegam N. Enumeration, ecology and ethnobotany of ferns of sirumalai hills, South India. J Econ Taxon Bot 2001;25:631-34.

7. Biswas TK, Mukherjee B. Plant medicines of Indian origin for wound healing activity: a review. Int J Lower Extremity Wounds 2003;2:25.

8. Taber CW. Taber's cyclopedic medical dictionary. $10^{\text {th }}$ edition. FA Davies Company, USA; 1965.

9. Ebi GC, Ofoefule SI. Investigation into the folkloric antimicrobial activities of Landolphia owerrience. J Phytol Res 1997;11:149-51.
10. Peterson JH. Welcome to Mycokey-the mycological information site; 2012. Available from: http://www.mycokey.com. [Last accessed on 20 Apr 2015]

11. Harborne JB. Phytochemical methods: a guide to modern techniques of plant analysis. Chapman and Hall Ltd, London; 1973.

12. Kiranmai M, Kazim SM, Ibrahim M. Combined wound healing activity of Gymnema sylvestere and Tagete serecta linn. Int. J Pharml Appl 2011;2:135-40.

13. Shrestha PM, Dhillion SS. Medicinal plant diversity of highlands of Dolakha district. Nepal J Ethnopharma 2003;86:81-96.

14. Arinathan V, Mohan VR. Ethno-medicinal survey among palliyar tribals of srivilliputhur grizzled giant squirrel wildlife sanctuary, Tamil Nadu. J Econ Taxon Bot 2003;2:707-10.

15. Somasekhar S, Saraswathi U, Laxminarayana U. Evaluation of antioxidant and wound healing effects of alcholic and aqueous extract of Ocimum sanctum Linn in Rats. eCAM 2008;5:95-101.

16. Chang R. Functional properties of edible mushrooms. Nutr Rev 1996;54:S91-S93.

17. Kavitha D, Balakumar R, Sivaprakasam E, Sridhar S, Suresh Kumar J. Antibacterial and antifungal potential of fruit body extracts from Daldinia concentrica (bolton) cesatiand de notaris. Int J Pharm Sci Res 2011;2: 2376-9.

18. Jonathan SG. Evaluation of the inhibitory potentials of eight higher nigerian fungi against pathogenic microorganisms. Afr J Biomed Res 2008;11:192-202.

19. Buwa LV, Staden JV. Antibacterial and antifungal activity of traditional medicinal plants used against venereal diseases in South Africa. J Ethnopharmacol 2006;103:139-42.

20. Parekh J. Efficacy of aqueous and methanol extracts of some medicinal plants for potential antibacterial activity. Turkish J Biol 2005;29:203-10.

21. Oryan A, Naeini AT, Nikahval B, Gorjian E. Effect of aqueous extract of Aloe vera on experimental cutaneous wound healing in rat. Vet Archive 2010;80:509-22.

22. Umachigi SP, Jayaveera KN, Ashok Kumar CK, Kumar GS, Vrushabendraswamy BM, Kishorekumar DV. Studies on wound healing properties of Quercus infectoria. Trop J Pharm Res 2008;7:913-9.

23. Somasekhar S, Saraswathi U, Laxminarayana U. Evaluation of antioxidant and wound healing effects of alcholic and aqueous extract of Ocimum sanctum Linn in Rats. eCAM 2008;5:95-101.

\section{How to cite this article}

- Rajeshwaran Thangaraj, Sumathy Raj, Kumuthakalavalli Renganathan. Wound healing effect of king alferd's mushroom (Daldinia concentrica) used by tribes of sirumalai hills, Tamilnadu, India. Int J Pharm Pharm Sci 2017;9(7):161-164. 